\title{
PENGGUNAAN SLIDE INTERAKTIF PADA PEMBELAJARAN DARING MATERI SUBSTANSI GENETIK UNTUK MENINGKATKAN ASPEK KOGNITIF SISWA
}

\author{
Anggitalina Pramilia Dewi
}

SMA Trensains Muhammadiyah Sragen

Email: anggitalinapramilia@gmail.com

\section{Info Artikel}

Sejarah Artikel:

Diserahkan 22 Maret 2021

Direvisi 05 April 2021

Disetujui 07 April 2021

\section{Keywords:}

classroom action research, interactive slide, online learning, cognitive aspects

\section{Abstract}

This research aims to determine the cognitive aspects enhancement of genetic substance material using interactive slide media in the online learning for students of Trensains Muhammadiyah high school grade twelve

This research is a classroom action research conducted in three cycles. Each cycles consist of four stages, they are; planning, implementing, observing, and reflecting. The subject in this research was a twelve grade students of Trensains Muhammadiyah high school sragen in academic year 2020/2021 with the amount 24 students. The data is processed through observation, questionnaire and test. The data analysis was conducted in a descriptive qualitative manner based on the results of observations and questionnaire as well as qualitatively on the result of cognitive test..

The result of the research shows that the number of students who achieved the minimum completeness score (KKM) 70 in the first cycle is 14 students $(58,33 \%)$, second cycle is 15 students $(62,5 \%)$, and third cycle is 18 students (75\%) from the subject amount 2424 students. Students cognitive ability increase in each cycle. The average of student cognitive aspect in cycle 1 is 73,3\%, cycle 2 is 76,7\%, and cycle 3 is 80,4\%. Based on the research, it can be concluded that the use of interactive slide media in the online learning of genetic substance material can improve cognitive aspects of student in grade XII MIPA 3 Trensians Muhammadiyah high school Sragen .

\begin{abstract}
Abstrak
Penelitian ini bertujuan untuk mendeskripsikan peningkatan aspek kognitif materi substansi genetik menggunakan media slide interaktif pada pembelajaran daring pada siswa kelas XII MIPA 3 SMA Trensains Muhammadiyah Sragen.

Penelitian ini merupakan Penelitian Tindakan Kelas yang dilaksanakan dalam tiga siklus. Setiap siklus terdiri dari empat tahapan yaitu perencanaan, pelaksanaan, pengamatan, dan refleksi. Subyek dalam penelitian ini adalah siswa kelas XII MIPA 3 SMA Trensains Muhammadiyah Sragen tahun pelajaran 2020/2021 yang berjumlah 24 siswa. Data diperoleh melalui metode observasi, kuesioner, dan tes. Analisis data dilakukan secara deskriptif kualitatif berdasarkan hasil observasi dan kuesioner, serta secara kuantitatif terhadap hasil tes aspek kognitif siswa.

Hasil penelitian menunjukkan bahwa jumlah siswa yang telah mencapai nilai ketuntatasan minimal (KKM) sebesar 70 pada siklus 1 sebanyak 14 siswa $(58,33 \%)$, siklus 2 sebanyak 15 siswa $(62,5 \%)$, dan siklus 3 sebanyak 18 siswa (75\%) dari total subjek penelitian yaitu 24 siswa. Kemampuan aspek kognitif siswa mengalami peningkatan pada setiap siklus. Ratarata aspek kognitif siswa di siklus 1 sebesar 73,3\%, pada siklus 2 sebesar 76,7\%, sedangkan siklus 3 sebesar $80,4 \%$. Berdasarkan hasil penelitian dapat disimpulkan bahwa penggunaan media slide interaktif pada pembelajaran daring materi substansi genetik dapat meningkatkan aspek kognitif siswa kelas XII MIPA 3 SMA Trensains Muhammadiyah Sragen
\end{abstract}




\section{Anggita Pramilia Dewi \\ PENGGUNAAN SLIDE INTERAKTIF PADA PEMBELAJARAN DARING MATERI SUBSTANSI .... WASIS: Jurnal Ilmiah Pendidikan. Volume 2, Nomor 1, Mei 2021, hlm. 55-61}

\section{PENDAHULUAN}

Belajar merupakan kegiatan utama dari keseluruhan proses pendidikan di sekolah yang bertujuan untuk menghasilkan perubahan tingkah laku. Menurut Nurhayati (2020), kegiatan pembelajaran memerlukan partisipasi dan komunikasi interaktif antara guru dan siswa. Pandemi Corona Virus Disease 2019 (Covid-19) adalah krisis kesehatan yang pertama dan terutama di dunia. Kebijakan lockdown atau karantina dilakukan sebagai upaya mengurangi interaksi banyak orang yang dapat memberi akses pada penyebaran virus corona.

Selama masa pandemi Covid-19, setiap satuan pendidikan di Indonesia melaksanakan pembelajaran dalam jaringan (daring) sebagai cara agar proses pembelajaran dapat terus berjalan. Putra (2020) mendefinisikan tentang pembelajaran daring sebagai proses pembelajaran yang tidak memperhitungkan ruang dan waktu pembelajaran serta bersifat mandiri untuk pengembangan siswa menggunakan metode dan teknik maupun media dalam kegiatan pembelajaran.

Pembelajaran biologi pada masa pandemi juga harus dapat dilakukan melalui pembelajaran daring. Berdasarkan hasil pengamatan selama pembelajaran daring, siswa sering mengalami kesulitan menyerap konsep materi yang abstrak tanpa adanya pembelajaran tatap muka secara langsung oleh guru. Oleh karena itu, model pembelajaran daring yang dilaksanakan menggunakan model blended learning tipe flipped classroom. Dimana pembelajaran tatap muka secara maya untuk penyampaian materi kognitif harus dilakukan melalui kegiatan synchronous menggunakan aplikasi google meet atau zoom meeting.

Kegiatan tersebut dilakukan setelah siswa melaksanakan kegiatan pembelajaran secara asynchronous dipandu oleh LMS, untuk melatih aspek psikomotorik dan afektif siswa. Upaya ini bertujuan agar guru dapat tetap berinteraksi langsung dengan siswa untuk menyampaikan materi, memberi penguatan, serta meluruskan konsep, setelah mereka melakukan kegiatan pembelajaran daring secara mandiri. Harapannya, siswa dapat memperoleh pemahaman materi secara maksimal walaupun kegiatan pembelajaran dilakukan dari jarak jauh.

Penyampaian materi secara synchronous tersebut menemui kendala di kelas XII MIPA 3. Latar belakang siswa yang juga merupakan santri di SMA Trensains Muhammadiyah Sragen sebagian besar berasal dari berbagai daerah di Indonesia dengan jaringan internet yang terbatas.
Jaringan internet kadang hanya cukup memfasilitasi siswa belajar secara asynchronous melalui LMS Schoology. Kegiatan pembelajaran yang mengasah kemampuan psikomotorik dan afektif siswa dapat terlihat dan tercapai melalui kegiatan pembelajaran secara asynchronous yang dipandu oleh LMS Schoology. Sedangkan dalam pembelajaran synchronous menggunakan google meet atau zoom meeting siswa belum dapat mengikuti secara maksimal karena terkendala oleh jaringan. Menurut Purwanto, dkk (2020), siswa akan menemukan kesulitan melakukan pembelajaran jarak jauh tanpa sarana dan prasarana memadai di rumah. Fasilitas ini sangat penting untuk kelancaran proses belajar mengajar dalam menyimak materi pembelajaran secara online.

Permasalahan tersebut diperkuat dengan temuan dari hasil Penilaian Tengah Semester (PTS) semester ganjil tahun ajaran 2020/2021 yang menunjukkan bahwa nilai siswa kelas XII MIPA 3 yang mencerminkan kemampuan aspek kognitif sangatlah kurang serta banyak siswa yang nilainya berada dibawah KKM.

Berdasarkan permasalahan tersebut, maka perlu dicari solusi yang tepat dalam penyampaian materi kognitif kepada siswa yang terkendala oleh jaringan. Menurut Julia (2019), pembelajaran dengan menggunakan media akan dapat membantu siswa memahami materi biologi, karena dengan media pembelajaran menghadirkan bentuk pembelajaran yang menarik.

Penggunaan media pembelajaran yang mengilustrasikan konsep materi abstrak seperti materi substansi genetika secara fleksibel dengan waktu dan tempat, dapat menggantikan penyampaian materi kognitif oleh guru ketika pembelajaran synchronous. Menurut Nikmah (2020) penggunaan media berbasis digital dapat membantu penaympaian materi pembelajaran. Siswa juga dapat mengaksesnya secara asynchronous, sehingga siswa tetap dapat menerima penyampaian materi kognitif secara maksimal walau dalam jaringan internet yang terbatas.

Media slide interaktif merupakan salah satu alternatif pilihan dalam membuat media pembelajaran pada materi substansi genetik (Suhermin, 2014). Media slide interaktif terdiri dari gabungan teks, gambar, video, animasi, dan suara berbasis microsoft powerpoint yang menjelaskan konsep substansi genetika kepada siswa ketika pembelajaran daring. Media slide interaktif mampu menyajikan proses yang tidak bisa didapatkan jika hanya menggunakan media 


\section{Anggita Pramilia Dewi \\ PENGGUNAAN SLIDE INTERAKTIF PADA PEMBELAJARAN DARING MATERI SUBSTANSI .... WASIS: Jurnal Ilmiah Pendidikan. Volume 2, Nomor 1, Mei 2021, hlm. 55-61}

tidak bergerak (buku teks atau gambar statis). Selain itu, media tersebut juga dapat menanamkan konsep dan pemaknaan yang sama dalam otak siswa dibandingkan dengan media lain seperti gambar statis.

Adapun tujuan dari penelitian ini adalah untuk mendeskripsikan peningkatan aspek kognitif materi substansi genetik menggunakan media slide interaktif melalui pembelajaran daring pada siswa kelas XII MIPA 3 SMA Trensains Muhammadiyah Sragen.

\section{METODE PENELITIAN}

Penelitian ini merupakan penelitian tindakan kelas (PTK). Penelitian tindakan kelas kali ini dilaksanakan dalam tiga siklus. Apabila siklus pertama tidak tuntas, maka dilanjutkan dengan siklus selanjutnya. Setiap siklus terdiri dari empat tahapan yaitu perencanaan, pelaksanaan, pengamatan, dan refleksi (Sukardiyono, 2015).

Subyek dalam penelitian ini adalah siswa kelas XII MIPA 3 SMA Trensains Muhammadiyah Sragen tahun pelajaran 2020/2021 yang berjumlah 24 siswa. Penelitian dilaksanakan di kelas XII MIPA 3 SMA Trensains Muhammadiyah Sragen dengan alamat Dusun Dawe, Desa Banaran, Kecamatan Sambungmacan, Kabupaten Sragen, Provinsi Jawa Tengah. Waktu penelitian dilaksanakan pada semester ganjil tahun pelajaran 2020/2021 yang pelaksanaannya antara bulan Oktober sampai bulan November tahun 2020.

Pengumpulan data dilaksanakan melalui kegiatan observasi berkaitan catatan lapangan selama tindakan pembelajaran berlangsung, pengisian angket kuesioner tanggapan siswa selama berlangsungnya proses pembelajaran, dan pelaksanaan posttest di setiap siklus yang mencerminkan aspek kognitif siswa. Beberapa instrumen penelitian yang digunakan dalam PTK ini adalah lembar observasi keterlaksanaan pembelajaran, kuesioner tanggapan siswa, dan soal pilihan ganda posttest hasil pengembangan dari kisi-kisi tes kognitif di setiap pertemuan pada semua siklus.

Analisis data dilakukan secara deskriptif kualitatif berdasarkan hasil observasi terhadap proses keterlaksanaan pembelajaran dan secara kuantitatif terhadap nilai posttes aspek kognitif siswa. Indikator keberhasilan peningkatan aspek kognitif siswa kelas XII MIPA 3 SMA Trensains Muhammadiyah Sragen adalah jika rata-rata nilai posttes siklus 1 meningkat dari rata-rata nilai PTS, rata-rata nilai posttes siklus 2 meningkat dari rata-rata nilai posttes siklus 1 , dan rata-rata nilai posttes siklus 3 meningkat dari rata-rata nilai posttes siklus 2. Selain itu, persentase jumlah siswa yang tuntas KKM mencapai $70 \%$ dari jumlah keseluruhan siswa.

\section{HASIL DAN PEMBAHASAN}

Pelaksanaan penelitian tindakan kelas ini dilakukan dalam 3 siklus. Siklus 1 pelaksanaan pembelajaran materi substansi genetik pada pertemuan pertama tentang kromosom dan gen. Dimulai dari menyusun rencana pembelajaran dengan strategi pembelajaran scientific dengan blended learning tipe flipped classroom, melalui model discovery learning, kemudian menyusun kelengkapan perangkat pembelajaran pendukung, seperti bahan ajar, LKPD, serta media slide interaktif menggunakan microsoft powerpoint. Kelengkapan perangkat pembelajaran yang telah disusun kemudian diunggah pada LMS Schoology. Setelah itu, siswa diarahkan untuk melaksanakan pembelajaran asynchronous terlebih dahulu dipandu oleh LMS Schoology.

Kegiatan pengamatan dilakukan selama proses pembelajaran synchronous oleh guru observer. Hasil observasi siklus 1 menunjukkan bahwa semua tahapan pembelajaran sudah terlaksana dengan baik, terlihat dari persentase keterlaksanaan pembelajaran sebesar $100 \%$. Catatan dari observer untuk guru hendaknya dapat lebih menanyakan kesulitan siswa dalam melaksanakan dan memahami materi pembelajaran.

Keadaan siswa terlihat antusias karena akan memasuki materi baru yaitu substansi genetika. Siswa senang menyaksikan video stimulasi dan berdiskusi membahas LKPD kromosom dan gen walaupun secara asynchronous. Hal tersebut terlihat dari hasil diskusi siswa pada LMS Schoology yang berisi beragam tulisan dan gambar untuk memecahkan permasalahan pada LKPD kromosom dan gen. Pada kegiatan synchronous melalui zoom meeting, siswa telah terampil melakukan share screen sambil menjelaskan hasil diskusi mereka. Keaktifan siswa tidak hanya melalui kamera dan suara, tetapi pemanfaatan chat juga dimaksimalkan sebagai sarana interaksi siswa yang terkendala alat dan jaringan.

Berdasarkan hasil kuesioner tanggapan siswa pada pembelajaran siklus 1 , siswa merasa senang dan terbantu dalam memahami materi pembelajaran dengan slide interaktif. Indriyana (2018) berpendapat bahwa tampilan slide interaktif yang menarik membuat minat siswa dalam mengikuti pembelajaran bertambah. Siswa lebih memilih belajar menggunakan slide 


\section{Anggita Pramilia Dewi \\ PENGGUNAAN SLIDE INTERAKTIF PADA PEMBELAJARAN DARING MATERI SUBSTANSI .... WASIS: Jurnal Ilmiah Pendidikan. Volume 2, Nomor 1, Mei 2021, hlm. 55-61}

interaktif daripada belajar menggunakan buku atau bahan ajar secara mandiri.

Data aspek kognitif siswa kelas XII MIPA 3 SMA Trensains Muhammadiyah Sragen pada siklus 1 menunjukkan bahwa media slide interaktif memberikan dampak positif, terlihat dari hasil rata-rata nilai posttes siklus 1 sebesar 73,3 menunjukkan peningkatan dari rata-rata nilai PTS semester ganjil sebesar 62,1. Siswa yang tuntas sejumlah 14 siswa dari 24 siswa, persentase ketuntasan sebesar 58,33\%, sehingga belum mencapai target. Hal ini disebabkan oleh beberapa faktor, diantaranya adalah kurang maksimalnya siswa menggunakan slide interaktif karena keterbatasan waktu pembelajaran synchronous. Ada beberapa siswa yang belum mengetahui bahwa slide interaktif sebenarnya dapat diakses pada LMS Schoology ketika pembelajaran asynchronous. Ketidakstabilan jaringan membuat proses pembelajaran mengalami delay sehingga banyak waktu yang terbuang, akhirnya waktu pembelajaran berkurang. Kemudian karena keterbatasan waktu tersebut, siswa mendapatkan penjelasan materi yang terlalu cepat dan kurang runtut.

Pelaksanaan posttest melalui LMS Schoology secara asynchronous juga belum ditegaskan secara jelas oleh guru, sehingga beberapa siswa baru mengetahui adanya posttest dan belum bisa mengumpulkan sesuai batas waktu yang telah ditentukan. Dari kendala tersebut, diperlukan persiapan yang lebih matang terkait manajemen waktu apabila terkendala jaringan agar penggunaan slide interaktif dapat berjalan maksimal, serta penjelasan informasi dan panduan pelaksanaan posttest dapat dipahami oleh siswa. Faktor-faktor yang mempengaruhi hasil tindakan silklus 1 tersebut dijadikan sebagai bahan perbaikan pelaksanaan siklus 2.

Perencanaan tindakan siklus 2 berdasarkan hasil refleksi siklus 1 . Siklus 2 dilaksanakan pada pertemuan kedua materi substansi genetika tentang DNA dan RNA. Catatan yang diberikan oleh observer yaitu sebagian besar tahapan telah dilakukan dengan baik, video apersepsi sangat aplikatif dan terkini, siswa sudah berperan aktif dalam kegiatan presentasi secara merata baik dari suara maupun chat.

Dalam pelaksanaan pembelajaran siklus 2, beberapa kelompok siswa terlihat lebih mengekspresikan kegiatan diskusi LKPD DNA dan RNA. Pada kolom diskusi LMS Schoology, terdapat beberapa video yang telah dibuat oleh siswa untuk menggambarkan proses pembuatan model DNA. Pada kegiatan synchronous melalui zoom meeting, siswa sudah terampil memperagakan model DNA, menjelaskan perbedaan tiap aspek DNA dan RNA, lalu mengidentifikasi setiap enzim replikasi DNA melalui interaksi suara maupun chat secara merata.

Berdasarkan hasil kuesioner tanggapan siswa pada pembelajaran siklus 2 , siswa mulai mengetahui kemudahan akses slide interaktif melalui LMS Schoology sehingga mereka dapat leluasa membukanya secara asynchronous. Selain itu, siswa mulai merasa tertantang untuk melakukan kegiatan diskusi secara asynchronous maupun presentasi secara synchronous ketika pembelajaran.

Data aspek kognitif siswa kelas XII MIPA 3 SMA Trensains Muhammadiyah Sragen menunjukkan rata-rata nilai posttes siklus 2 sebesar 76,7 menunjukkan peningkatan dari ratarata nilai posttes siklus 1 sebesar 73,3. Siswa yang tuntas sejumlah 15 siswa dari 24 siswa, sehingga persentase ketuntasan sebesar $62,5 \%$ dan masih belum mencapai indikator keberhasilan yaitu sebesar $70 \%$. Hal ini disebabkan oleh beberapa faktor, diantaranya adalah ketidakstabilan jaringan seperti siklus sebelumnya. Pengelolaan waktu berusaha diatur oleh guru sehingga penggunaan slide interaktif dapat lebih optimal. Penjelasan guru agak diperlambat sehingga urutan materi dapat terlihat sistematis dan siswa lebih mudah memahami materi pembelajaran. Namun, pelaksanaan pembelajaran siklus 2 ini melebihi waktu pembelajaran normal, sehingga terpaksa mengambil jam pelajaran berikutnya. Siswa merasa keberatan atas hal tersebut, karena mereka tidak dapat melaksanakan pembelajaran pada mata pelajaran berikutnya.

Dari kendala tersebut, diperlukan persiapan yang lebih matang terkait manajemen waktu agar tidak melebihi waktu pembelajaran yang sebenarnya, serta penjelasan informasi dan panduan pelaksanaan posttest dapat dipahami oleh siswa. Faktor-faktor yang mempengaruhi hasil tindakan siklus 2 tersebut dijadikan sebagai bahan perbaikan pelaksanaan siklus 3 .

Perencanaan tindakan siklus 3 berdasarkan hasil refleksi siklus 2. Siklus 3 dilaksanakan pada pertemuan ketiga materi substansi genetika tentang sintesis protein. Catatan yang diberikan oleh observer yaitu semua tahapan telah dilakukan dengan baik, video apersepsi menghubungkan materi dengan nilai agama sehingga siswa lebih mudah mengambil manfaat. Penguatan oleh guru tidak 


\section{Anggita Pramilia Dewi \\ PENGGUNAAN SLIDE INTERAKTIF PADA PEMBELAJARAN DARING MATERI SUBSTANSI .... WASIS: Jurnal Ilmiah Pendidikan. Volume 2, Nomor 1, Mei 2021, hlm. 55-61}

hanya melalui slide interaktif tetapi juga menggunakan cerita analogi sehingga siswa lebih memahami urutan proses sintesis protein.

Dalam pelaksanaan pembelajaran siklus 3, siswa terlihat lebih bersemangat dan berantusias dalam berinteraksi seperti bertanya, menjawab pertanyaan, dan memberikan tanggapan. Kegiatan pembelajaran yang lebih menekankan pada penilaian proses membuat siswa termotivasi untuk berpartisipasi aktif dalam pembelajaran walau dilakukan secara daring. Kegiatan penilaian pembelajaran secara asynchronous melalui kuis di LMS Schoology sudah ditegaskan oleh guru.

Berdasarkan hasil kuesioner tanggapan siswa pada pembelajaran siklus 3 , siswa merasa senang belajar daring menggunakan slide interaktif dan berharap dapat menggunakan media tersebut pada materi yang lain. Selain itu, siswa berhasil mengambil manfaat dari keseluruhan materi substansi genetika setelah dihubungkan dengan ilmu agama. Siswa menjadi lebih termotivasi untuk mempelajari materi karena merasa takjub dengan sistem tubuh manusia dalam menghasilkan protein.

Data aspek kognitif siswa kelas XII MIPA 3 SMA Trensains Muhammadiyah Sragen menunjukkan hasil rata-rata nilai postest siklus 3 sebesar 80,4 menunjukkan peningkatan dari ratarata nilai posttes siklus 2 sebesar 76,7. Siswa yang tuntas sejumlah 18 siswa dari 24 siswa, persentase ketuntasan sebesar $75 \%$ sehingga telah mencapai indikator keberhasilan lebih dari $70 \%$. Hasil tindakan pada siklus 3 berhasil mencapai target disebabkan oleh beberapa saran dan masukan yang sudah didapatkan dari siklus 1 dan 2. Segala masukan tersebut digunakan sebagai bahan revisi atau perbaikan pada siklus 3. Diantaranya, upaya guru dan teknisi untuk memaksimalkan jaringan agar pembelajaran synchronous lebih lancar sehingga waktu pembelajaran lebih efektif tanpa harus mengambil jam pelajaran berikutnya. Selain itu, guru sudah menjelaskan informasi dan panduan pelaksanaan penilaian kognitif melalui postest secara asynchronous pada LMS Schoology sehingga siswa segera mengerjakan penilaian dan dapat diselesaikan tepat waktu.

Penggunaan slide interaktif terus ditekankan oleh guru agar siswa dapat memanfaatkannya melalui kegiatan asynchronous di LMS Schoology semaksimal mungkin. Hasil penelitian berupa data aspek kognitif yang terlihat mengalami peningkatan pada rata-rata nilai posttest dan persentase ketuntasan di setiap siklusnya disajikan pada tabel berikut:

Tabel 1. Rekapitulasi rata-rata nilai posttest dan persentase ketuntasan

\begin{tabular}{lcc} 
Siklus & $\begin{array}{c}\text { Rata-rata Nilai } \\
\text { Postest }\end{array}$ & $\begin{array}{c}\text { Persentase } \\
\text { Ketuntasan }\end{array}$ \\
\hline PTS & 62,1 & $20,8 \%$ \\
Siklus 1 & 73,3 & $58,33 \%$ \\
Siklus 2 & 76,7 & $62,5 \%$ \\
Siklus 3 & 80,4 & $75 \%$ \\
\hline
\end{tabular}

Hasil observasi yang dilakukan oleh observer pada saat siklus 1, 2, dan 3 memperlihatkan bahwa kemampuan peneliti sebagai guru dalam melaksanakan pembelajaran daring sudah mengalami peningkatan di setiap siklusnya. Berdasarkan hasil analisis yang dilakukan terhadap aspek kognitif siswa mengalami peningkatan. Peningkatan aspek kognitif siswa disebabkan oleh penggunaan media slide interaktif pada kegiatan synchronous maupun asynchronous. Menurut Indriyanti (2017) penggunaan media slide interaktif membantu siswa memahami materi pembelajaran sehingga dapat meningkatkan hasil belajar. Menurut Maharani dan Basir (2016) dalam penggunaan media $\mathrm{CD}$ interaktif dapat meningkatkan kemampuan pemecahan masalah siswa. Hal tersebut juga sejalan dengan pendapat Risqi (2016) bahwa penggunaan media pembelajaran interaktif dapat membantu siswa dalam pemecahan masalah. Dalam pembelajaran asynchronous, siswa melakukan kerjasama ketika mereka melakukan diskusi melalui LMS Schoology. Siswa juga terlihat aktif pada saat pembelajaran synchronous dengan berani bertanya, berani menjawab dan berani mengemukakan pendapat.

Penggunaan media pembelajaran yang menyajikan materi pembelajaran secara teks, audio, maupun visual akan lebih cepat ditangkap oleh siswa (Septiani, 2016). Penggunaan media pembelajaran yang mengilustrasikan konsep materi abstrak seperti materi substansi genetika secara fleksibel dengan waktu dan tempat, dapat menggantikan penyampaian materi kognitif oleh guru ketika pembelajaran synchronous. Siswa juga dapat mengaksesnya secara asynchronous, sehingga siswa tetap dapat menerima penyampaian materi kognitif secara maksimal walau dalam jaringan internet yang terbatas.

Media slide interaktif merupakan salah satu alternatif pilihan dalam membuat media pembelajaran pada materi substansi genetik 


\section{Anggita Pramilia Dewi \\ PENGGUNAAN SLIDE INTERAKTIF PADA PEMBELAJARAN DARING MATERI SUBSTANSI .... WASIS: Jurnal Ilmiah Pendidikan. Volume 2, Nomor 1, Mei 2021, hlm. 55-61}

(Suhermin, 2014). Media slide interaktif terdiri dari gabungan teks, gambar, video, animasi, dan suara berbasis microsoft powerpoint yang menjelaskan konsep substansi genetika kepada siswa ketika pembelajaran daring. Menurut Zain (2020) menyatakan bahwa media interaktif mampu menyajikan proses yang tidak bisa didapatkan jika hanya menggunakan media tidak bergerak (buku teks atau gambar statis). Hal tersebut sejalan dengan pendapat Jalil (2016) bahwa penggunaan media power point interaktif menjadikan siswa tidak bosan dalam pembelajaran karena siswa dapat berinteraksi secara langsung dengan media pembelajaran tersebut. Selain itu, media tersebut juga dapat menanamkan konsep dan pemaknaan yang sama dalam otak siswa dibandingkan dengan media lain seperti gambar statis.

Pengalaman peneliti sebagai guru yang mengajar langsung pembelajaran, sangat mengembangkan kompetensi pedagogic dan profesional. Awalnya peneliti masih kesulitan dalam manajemen waktu sehingga ada beberapa materi yang kurang tersampaikan dengan lengkap dan kurang menguasai kelas berbentuk daring sehingga masih ada siswa yang kesulitan mengikuti pembelajaran karena terkendala jaringan. Setelah adanya refleksi, peneliti sudah mulai memperbaiki kekurangan-kekurangan tersebut. Analisis data dari nilai aspek kognitif, hasil observasi keterlaksanaan pembelajaran, dan kuesioner tanggapan siswa mengindikasikan bahwa penggunaan slide interaktif pada pembelajaran daring memberikan pengaruh positif terhadap aspek kognitif siswa kelas XII MIPA 3 SMA Trensains Muhammadiyah Sragen.

\section{SIMPULAN}

Berdasarkan hasil penelitian tindakan kelas ini dapat disimpulkan bahwa penggunaan media slide interaktif pada pembelajaran daring materi substansi genetik dapat meningkatkan aspek kognitif siswa kelas XII MIPA 3 SMA Trensains Muhammadiyah Sragen.

\section{DAFTAR PUSTAKA}

Indriyana. 2018. Pengembangan Media Slide Interaktif Berbasis Powerpoint pada Submateri Invertebrata di SMA Negeri 1 Tekarang. Jurnal Untan.

Indriyanti, Novi Yulia. 2017. Pengembangan Media Pembelajaran Interaktif Berbasis PPT untuk Meningkatkan Hasil Belajar IPS Materi Keragaman Suku Bangsa dan
Budaya Studi Kasus: Siswa Kelas VB SDN Karangayu 02 Kota Semarang. Jurnal Digilib Unnes.

Jalil, M. (2016). Pengembangan Pembelajaran Model Discovery Learning berbantuan tips powerpoint interaktif pada materi interaksi makhluk hidup dengan lingkungan. Refleksi Edukatika: Jurnal Ilmiah Kependidikan, 6(2).

Julia, Heni. 2019. Pengembangan Media Powerpoint Interaktif pada Materi Bioteknologi di SMA. Jurnal Repository UM-Palembang.

Maharani, H. R., \& Basir, M. A. (2016). Pengembangan Media CD Interaktif Matematika Untuk Meningkatkan Kemampuan Pemecahan Masalah Siswa SMP. Refleksi Edukatika: Jurnal Ilmiah Kependidikan, 7(1), 31-34.

Nikmah, Nurul., dkk. 2020. Penerapan Media Pembelajaran Math Mobile Learning untuk Meningkatkan Kemampuan Pemecahan Masalah Siswa Kelas IV. WASIS: Jurnal Ilmiah Pendidikan.1(2): 1-8.

Nurhayati, Erlis. 2020. Meningkatkan Keaktifan Siswa Dalam Pembelajaran Daring Melalui Media Game Edukasi Quiziz pada Masa Pencegahan Penyebaran Covid-19. Jurnal Paedagogy: Jurnal Penelitian dan Pengembangan Pendidikan, 7(3): 145-150.

Purwanto, Agus., dkk. 2020. Studi Eksploratif Dampak Pandemi COVID-19 Terhadap Proses Pembelajaran Online di Sekolah Dasar. EduPsyCouns Journal, 2(1): 1-12.

Putra, Reza A.M. 2020. Kendala Pelaksanaan Pembelajaran Jarak Jauh (PJJ) dalam Masa Pandemi. Jakarta: Universitas Negeri Jakarta.

Risqi, H. (2016). Pengembangan Media CD Interaktif Matematika Untuk Meningkatkan Kemampuan Pemecahan Masalah Siswa Smp. Refleksi Edukatika: Jurnal Ilmiah Kependidikan, 6(1).

Septiani, Erna. 2016. Pengembangan Media Pembelajaran Interaktif dengan Aplikasi Powerpoint Add-Ins Ispring pada Mata 
Anggita Pramilia Dewi

PENGGUNAAN SLIDE INTERAKTIF PADA PEMBELAJARAN DARING MATERI SUBSTANSI .... WASIS: Jurnal Ilmiah Pendidikan. Volume 2, Nomor 1, Mei 2021, hlm. 55-61

Pelajaran Biologi Materi Sel Peserta Didik Kelas XI. Jurnal Repository Raden Intan.

Suhermin., dkk. 2014. Profil Media Slide Interaktif Berbasis MS. Powerpoint pada Pokok Bahasan Substansi Genetika Kelas XII. BioEdu Jurnal, 3(1): 333-337.

Sukardiyono, Totok. 2015. Pengertian, Tujuan, Manfaat, Karakteristik, Prinsip, dan Langkah-Langkah Penelitian Tindakan Kelas. Yogyakarta: Universitas Negeri Yogyakarta.

Zain, Ayi. 2020. Pengaruh Penggunaan Media Game Interaktif terhadap Hasil Belajar Materi Substansi Materi Genetik Siswa Kelas XII MIA SMA Muhammadiyah Limbung Kabupaten Gowa. Jurnal Digilib Unismuh. 